\author{
Alen Belullo* \\ Tina Dužman ${ }^{*}$ \\ UDK 330.55:336.14>(497.5)’2000/2010” \\ Pregledni rad
}

\title{
RELATIONS AMONG GOVERNMENT REVENUES AND GROSS DOMESTIC PRODUCT (GDP) OF THE REPUBLIC OF CROATIA
}

\begin{abstract}
A B S T R AC T
The aim of this paper is to analyse the relations between the gross domestic product (GDP) and budget revenues of the Republic of Croatia in the period from the first quarter of 2000 to the first quarter of 2010.

Vector autoregressive model is used for the analysis. The interdependence between selected macroeconomic values was examined using cointegration analysis, which has proved that there is statistically significant, long-run stable relationship between the GDP and budget revenues.

Granger Causality Test has proved that GDP in the Granger sense has a significant impact on changes in state revenues.
\end{abstract}

JEL: E00, E01

Keywords: cointegration analysis, Granger causality, GDP, budget revenues.

\section{INTRODUCTION}

Numerous papers are dealing with the fiscal policy and are focused on current macroeconomic issues such as budget deficits, public debt and reduction of budget expenditures.

This paper analyzes the relationship between budget revenues of the Republic of Croatia and its GDP in the period from the first quarter of 2000 to the first quarter of 2010. For the purpose of this analysis, we used current revenues, because tax revenues are the most important source of state revenues and GDP. Both indicators are expressed in the actual values to avoid the impact of inflation on the survey results. The interdependence between macroeconomic values of gross domestic product and budget revenues is being investigated through cointegration analysis to determine whether there is a long-run linear relationship between these variables and their speed of adjustment towards that long-run linear combination. In order to confirm the results obtained from the cointegration analysis, we performed Granger Causality Test between the variables.

\footnotetext{
* docent, Juraj Dobrila University of Pula, Department of Economics and Tourism "Dr. Mijo Mirković", E-mail adress: abelul@efpu.hr

* student, Juraj Dobrila University of Pula, Department of Economics and Tourism "Dr. Mijo Mirković", E-mail adress: tduzman@efpu.hr
} 


\section{OVERVIEW OF CURRENT EMPIRICAL RESEARCH}

Many papers have been written in Croatia and abroad on the connection between the indicators of economic activity and budget variables. M. Benazic (2006) researched the impact of fiscal policy on economic activity. The author of the analysis used monthly data expressed in real values for the period from the January 1995 to the April 2004. In the analysis he used the following variables: budget revenues, budget expenditures and GDP. The analysis was performed using cointegration analysis and vector error correction model. The results show the possibility that an increase in government revenues will have a negative impact on real economic activity while government expenditures will have a positive impact on real economic activity. The importance of the effects of budget revenues was also established, which influence in the long-run declines. S. Svaljek, M. Vizek, A. Mervar (2009) calculated the cyclically adjusted budget balance in order to obtain a clearer picture of the fiscal trends and analysis of fiscal policy in Croatia. For this analysis, the authors identified cyclically sensitive budget revenues and expenditures and then calculated the trend values of macroeconomic base using Hodrick-Prescott filter techniques. The elasticity of cyclically sensitive budget components, with respect to their macroeconomic bases, is calculated with an error-correction model. The analysis covered the period from the first quarter of 1995 to the third quarter of 2008. The results of the exercise indicated that both periods of pro- and anticyclical fiscal policies have been present in the analyzed period with the restrictive and procyclical policy prevailing in the recent years. H. Simunic analyzed the interdependence between the taxation and the economic growth (2008). The analysis was performed on monthly data for the period from July 2004 to the June 2008. The analysis used two variables, budget revenues and the index of industrial production. In the econometric analysis the author used the regression analysis to confirm the significant taxation-economic growth relation, and the vector auto-regression (VAR) model to explore the interaction of taxation and economic growth in Croatia. In the analysis of VAR model he used Granger Causality Test, an orthogonal decomposition of the variance and impulse response analysis. With this econometric analysis the author proved the correlation between the taxation and the economic growth in Croatia. He also proved that there is mutual influence between taxation and economic growth, but that taxation has more significant affect on the economic growth. $\mathrm{M}$. Tkalec and M. Vizek analyzed the impact of macroeconomic policies on manufacturing production in Croatia (2009.). The analysis was conducted for the period from the first quarter of 1998 to the third quarter of 2008. They used multiple regressions model. Chosen independent variables were personal consumption, investments, interest rates, the real effective exchange rate, government consumption, fiscal deficit and foreign demand, while the manufacture of the specific manufacturing sector was the dependant variable (they analyzed the total of 22 manufacturing sectors). The results suggest that changes in fiscal conditions, the real effective exchange rate and personal consumption mostly affect low technological intensity industries. Changes in investments, foreign demand and fiscal policy strongly affect the production in high technological intensity industries. It was concluded that fiscal policy is particularly important for manufacturing industry due to two reasons, the fiscal elasticity and shorter time lags for the impact of fiscal policy. D. Rukelj (2009) used structural vector error correction model to explore the interactions of fiscal and monetary policy, and economic activity in Croatia. He analyzed monthly data for the period from the January 1997 to the December 2008. The variables used in the analysis are expressed in real values. They are government expenditures, monetary aggregates M1 and the index of economic activity. The conclusion of this paper is that the monetary and fiscal policy affect economic activity, but are often used as substitutes and move in the opposite direction. The author also 
concluded that an aggregate supply shock has a statistically significant permanent effect on all three observed variables in the long-run.

C. Gray, T. Lane, A. Varoudakis conducted the research for the World Bank on the topic of fiscal policy and economic growth (2007). The research was conducted on the basis of regression analysis on panel data of 57 developed and developing countries (countries of Central and Eastern Europe and Central Asia), which are grouped into three groups depending on the level of national income. One of the results of this analysis is that the higher GDP/ per capita is associated with the higher tax rates. It has been noted that countries with higher national income had a statistically significant higher taxes than other countries involved in the analysis. Research of the European Central Bank (2003) on the impact of fiscal policy on long-run economic growth in the EU was based on the analysis of panel data for all EU countries, for the period from 1961 to 2001. The analysis used data on government revenues and expenditures, and GDP of all EU member states. The aim was to empirically prove the extent to which fiscal policy reform in the EU affects the economic growth. The main conclusion is that government expenditures have impact on long-run growth during the business cycle. Cointegration analysis proved a strong correlation between budgetary revenues and expenditures. It was proved that government spending and government transfers have a negative impact on economic growth, while state investments have a positive impact on economic growth. The impact of taxes on economic growth was not clearly proven, but based on the available data it was concluded that direct taxes have a negative impact on the accumulation of capital. G. Karras and D. Furceri (2009.) also investigated the effects of changes in taxes on economic growth in EU. The authors used panel data from 1965 to 2003 for a panel of nineteen European economies. Used variables were the total tax rate, corporate tax, income tax and capital gains, social security contributions, property taxes, taxes on goods and services and GDP / per capita. The results show that an increase in the tax has a negative impact on long-run growth in the EU. According to this research, an increase in the total tax rate by $1 \%$ of GP will have a long-run effect on GDP per capita of $0,5 \%$ and $1 \%$. The European Central Bank (2008) analysed the effects of size and volatility of government revenue and spending on growth in OECD and EU 15 countries. The research was based on the analysis combined cross-section time-series regressions for seven five-year periods from 1970 to 2004. The results show that both variables are determinal to growth. According to this research a percentage point increase in the share of total revenue in GDP would decrease output growth by 0.12 percentage points both for the OECD and the EU countries, but revenue volatility does not significantly affect growth. The main conclusion is that effect of government revenues ratios squared does not depend on the relative size of government. Barro and Redlick (2009) analysed macroeconomic effects from government purchases and taxes in USA. They described their empirical framework (time series from 1912 to 2006) for assessing effects on real GDP from changes in government purchases, taxes and other variables. Samples since 1950 indicate substantial and significantly negative effects from changes in average marginal income-tax rates on real GDP growth.

\section{RESEARCH METHODOLOGY}

Statistical relationship between the variables of government revenue and gross domestic product is analyzed using cointegration analysis and Granger causality test.

Both methods use vector autoregression (VAR) environment. $K$-dimensional reduced vector autoregressive model of order $p$ looks like:

$$
z_{t}=v+A_{1} z_{t-1}+\cdots+A_{p} z_{t-p}+u_{t}
$$


where $z_{t}=\left(z_{1 t}, \cdots, z_{K t}\right)^{\prime}$ is $K$-dimensional vector of random variables, $A_{i}$ are matrices of fixed coefficients $(K \times K), v=\left(v_{1}, \cdots, v_{K}\right)$ is $K$-dimensional vector of constants, $u_{t}$ is $K$ dimensional process with white noise for which $E\left(u_{t}\right)=0, E\left(u_{t} u_{t}^{\prime}\right)=\Sigma_{u}$, $E\left(u_{t} u_{s}^{\prime}\right)=0$ for $s \neq t$.

VAR order i.e. the number of lags crucial for its dynamics, is tested with Akaika (AIC), Hannan and Quinna and Schwartz (SC) criterion and (HQ) criterion, by minimizing their values.

The quality of vector autoregression model is verified by testing the normality of distribution and residual autocorrelation. Normality of distribution of residuals is tested with the multivariate version of Shenton-Bowman test offered by Doornika and Hansen ${ }^{1}$.

Residual autocorrelation is tested with Ljung-Box test of autocorrelation developed by Godfrey $^{2}$. Heteroskedasticity of residuals are tested by ARCH tests.

If we assume that elements of vector $z_{t}$ from (1) integrates variables of order $I(1)$ :

$z_{t}=v+A_{1} z_{t-1}+\cdots+A_{p} z_{t-p}+u_{t}$,

and if we subtract from both sides of the equation $z_{t-1}$, after sorting we get:

$$
\Delta z_{t}=v+\Pi z_{t-1}+\Gamma_{1} \Delta z_{t-1}+\cdots+\Gamma_{p-1} \Delta z_{t-p+1}+u_{t}
$$

where $\Pi=\alpha \beta^{\prime}$. $\beta^{\prime}$ is cointegration matrix or matrix of cointegration vectors and $\alpha$ is socalled loading matrix whose parameters indicate the speed of adjustment of the variables to long-run equilibrium shown with cointegration vectors.

If variables are cointegrated, it means that there is a long-run linear relationship between them. It is apparent that cointegration vectors are not unique. Namely, if $\beta=\left(\beta_{1}, \beta_{2}, \ldots, \beta_{K}\right)$ ' is cointegration vector, then for each $\lambda \neq 0$ exists cointegration vector $\left(\lambda \beta_{1}, \lambda \beta_{2}, \ldots, \lambda \beta_{K}\right)$ '. This means that all dependent vectors of cointegration vector $\beta$ are also cointegration vectors themselves. Therefore, the cointegration vector can be normalized by some variable.

Since the values $\alpha$ and $\beta$ in the matrix $\Pi$ must be simultaneously determined, then ordinary least square (OLS) method is not suitable for evaluation of model parameters (2). Therefore, the evaluation of parameters is based on the method of maximum likelihood developed by Johansen and Juselius ${ }^{3}$ and Johansen ${ }^{4}$. Johansen likelihood ratio test is used to test cointegration rang $\lambda$ trace:

$\lambda_{\text {trace }}(r)=-T \sum_{i=r+1}^{p} \ln \left(1-\hat{\lambda}_{i}\right)$.

$\lambda_{\text {trace }}$ statistics tests the null hypothesis that the number of different cointegration vectors is less than or equal to $r$ against the alternative hypothesis that it is higher.

Since the processes in equation (2) are stationary in first difference if the processes, which enter the analysis, are I (1) processes, i.e. processes of the first order of integration, testing whether this is deterministic or stochastic trend is done with the augmented DickeyFuller (ADF) test and Phillips-Perron test.

\footnotetext{
${ }^{1}$ Doornik, J. A., Hansen, H., An Omnibus Test for Univariate and Multivariate Normality, Working Paper, Nuffield College, Oxford, 2005.

${ }^{2}$ Godfrey, L. G., Misspecification Tests in Econometrics; the Lagrange Multiplier and other Approaches, Cambridge University Press, 1988.

${ }^{3}$ Johansen S., K. Juselius, Maximum Likelihood Estimation and Inference on Cointegration with Application to the Demand for Money, Oxford Bulettin of Economics and Statistics 52, 1990., str. 169-209.

${ }^{4}$ Johansen S., Likelihood-Based Inference in Cointegrated Vector Auto-Regression Models, Oxford Univerity Press, 1995.
} 
In 1969 Granger $^{5}$ defined the concept of causality, which can easily be tested in the autoregressive VAR structure. Granger causality is based on the idea that an effect can not precede its cause. Therefore, if the variable $x$ causes variable $y$, the variable $x$ should contribute to the forecast of the variable $y$ since the variable $x$ with lags contains additional information on variable $y$. Conversely, we can test whether there exists a feedback impact of the variable $y$ on variable $x$.

In the VAR structure we can easily test whether, in Granger sense, variable $x$ causes variable $y$ by simply testing VAR coefficients in a way that all coefficients associated with the variable $x$, in the equation of the variable $y$ of reduced VAR are equated to zero. If this constraint is not statistically significant, it is said that the variable $x$ does not cause, in the Granger sense, the variable $y$. As all equations in reduced VAR are evaluated independently from each other, we can test the common parameters of a single VAR equation with a simple F-test. It is clear that one can test the effect of the variable $y$ on variable $x$ in a similar way.

\section{RESEARCH RESULTS}

\section{DATA}

Data on real GDP in Croatia in prices in year 2005 are taken from IFS (International Financial Statistics), a database of the International Monetary Fund. Information about current government revenues are taken from the Ministry of Finance and are reduced to a real category in prices in 2005. In this way, we can compare the absolute changes in variables, both expressed in the prices in 2005. Since Croatian government revenues as well as Croatian GDP show significant seasonal variations, we used X11 ARIMA methodology to create seasonal adjustments of the variables. In other words, the further analysis was entered with the seasonally adjusted quarterly data, with the real size of the variables expressed in the prices for 2005, for the period from the first quarter of 2000 to the first quarter of 2010.

Stationarity of the data included in the cointegration analysis was tested using the $\mathrm{ADF}$ and PP tests. SBIC (Schwartz Bayesian Information Criterion) criterion is used to select the length of the autoregressive components.

Table 1.: Testing the unit eigenvalues of the process

\begin{tabular}{|l|l|l|l|l|l|l|}
\hline \multirow{2}{*}{ Variable } & \multicolumn{4}{l|}{ At level } & \multicolumn{3}{l|}{ In first difference } \\
\cline { 2 - 7 } & det. components: $c, t$ & \multicolumn{4}{l|}{ det. comp.: $c$} \\
\cline { 2 - 7 } & lag & ADF & PP & lag & ADF & PP \\
\hline REVENUES & 0 & -1.91 & -5.97 & 1 & $-5.97^{* *}$ & $-84.05^{* *}$ \\
\hline GDP & 0 & -0.64 & -1.98 & 0 & $-5.36^{* *}$ & $-35.27^{* *}$ \\
\hline
\end{tabular}

* statistically significant at the significance level of $5 \%$

** statistically significant at the significance level of $1 \%$

Table 1 shows the results of testing stationarity of the processes that are included in the analysis. As the processes at level show trends, we approached the testing with the trend and constant as deterministic components. In this way, we tested whether the trend in variables is of a deterministic or stochastic nature. From Table 1, it is evident that for the variable Revenues and the variable GDP we can not reject the hypothesis about the unit root in the presence of a deterministic trend. Therefore, it can be concluded that their visible trends are of stochastic nature, and that these variables can be stationed so that they can be

\footnotetext{
${ }^{5}$ C.W.J.Granger,’Investigating Causal Relations by Econometric Models and Cross Spectral Methods”, Econometrica, 37, 1969., str. 424- 
differentiated. When variables are differentiated from Table 1 it is evident from the augmented Dickey-Fuller test with a constant deterministic component that both variables are stationary in the first difference. This suggests that the variables GDP and Revenues are processes of the first order of integration I (1), which are suitable for cointegration analysis.

\section{COINTEGRATION ANALYSIS}

Quality cointegration analysis is based on the quality VAR model. Important decision about VAR model shown in equation (1) is his order, i.e. the number of lags to be included in the model. The decision on the number of lags was made on the basis of three criteria: the Akaike, Hannan-Quinn and Schwartz criterion. The test results are shown in Table 2.

Table 2.: Lag selection criteria for VAR model

\begin{tabular}{|c|c|c|}
\hline Lag AIC & \multicolumn{2}{|c|}{$\begin{array}{ll}\mathrm{HQ} & \mathrm{SC}\end{array}$} \\
\hline $1 \quad 27.26444$ & 27.32550 & 27.43333 \\
\hline $2 \quad 27.12074$ & 27.24317 & 27.46198 \\
\hline $\begin{array}{ll}3 & 27.13911\end{array}$ & 27.32311 & 27.65625 \\
\hline $4 \quad 27.16439$ & 27.40998 & 27.86100 \\
\hline $5 \quad 27.38387$ & 27.69092 & 28.26360 \\
\hline
\end{tabular}

Based on Table 2 it is apparent that AIC and HQ suggest two lags while the SC criterion indicates one time lag. In the event of disagreement in criteria about the optimal lag Reimers ${ }^{6}$ concludes that HQ is superior information criterion relative to other criteria and that the Schwartz criterion is biased towards one lag. One can therefore conclude that the optimal number of lags for the VAR on which to base the cointegration analysis is 2, or second-order VAR.

Table 3 shows the results of testing the VAR model residuals. Residuals are not autocorrelated, as evidenced in the Ljung-Box test, they are normally distributed (ShentonBowman test) and there is no trace of heteroskedasticity (ARCH tests). In other words, the VAR model is correctly specified and therefore the conclusions derived from this model are statistically significant and valid.

Table 3.: Diagnostics for VAR model

\begin{tabular}{|c|c|}
\hline \multicolumn{2}{|c|}{ Tests for Autocorrelation } \\
\hline Ljung-Box(9): & ChiSqr(30) = 39.624 [0.112] \\
\hline $\mathrm{LM}(1)$ & $\operatorname{ChiSqr}(4)=6.321[0.176]$ \\
\hline $\operatorname{LM}(2):$ & ChiSqr $(4)=7.171[0.127]$ \\
\hline Test for Normality & ty: $\operatorname{ChiSqr}(4)=0.915$ [0.922] \\
\hline Test for ARCH: & \\
\hline $\operatorname{LM}(1)$ & ChiSqr(9) = 3.953 [0.914] \\
\hline $\operatorname{LM}(2):$ & ChiSqr $(18)=7.911[0.980]$ \\
\hline
\end{tabular}

\footnotetext{
${ }^{6}$ Reimers H. E., Lag order determination in cointegrated VAR systems with application to small German MacroModels, WP, ESEM, UPPSALA, 1993.
} 
Table 4 shows Johansen's likelihood ratio test $\lambda_{\text {trace }}$. The first column shows the $(K-r$ or the number of endogenous variables minus the rank of matrix $\Pi$ ), which indicates the number of common trends among the variables, the second column shows the rank of matrix $\Pi$, the third column shows the value of the eigenvalues ordered from larger to smaller, the fourth column shows $\lambda_{\text {trace }}$ statistics, the fifth column shows the critical values for the $95 \%$ reliability and the last column shows the level of test significance. Based on the test with 95\% of reliability, we can reject the hypothesis that the intrinsic value (0.440) of matrix $\Pi$ is equal to zero, while for the intrinsic value of 0.179 we can not reject the hypothesis that it is zero. Since the rank of certain matrix is equal to the number of eigenvalues of matrix which are different from zero, it can be concluded that there exists an inherent value statistically significantly different from zero and that rank $(\Pi)=1$, the matrix in equation (2). In other words, it can be concluded that there is a long-run stationary relationship between the variable Revenues and GDP.

Table 4.: Johansen's likelihood ratio test

\begin{tabular}{cccccc}
\hline \hline \multicolumn{6}{c}{$\lambda_{\text {trace }}$ test ranga matrice $\Pi$} \\
\hline \hline K-r & r & Eig.Value & Trace & Frac95 & P-Value \\
\hline 2 & 0 & 0.440 & 30.294 & 20.164 & 0.001 \\
$\mathbf{1}$ & $\mathbf{1}$ & $\mathbf{0 . 1 7 9}$ & 7.711 & $\mathbf{9 . 1 4 2}$ & $\mathbf{0 . 0 9 5}$ \\
\hline
\end{tabular}

Table 5 shows the decomposition of the matrix $\Pi$ in equation (14) on cointegration vector $\beta$ (normalized by variable Revenues) and loading matrix $\alpha$ that indicates the speed of adjustment of the variables to a long-run equilibrium. In parentheses are given $t$ values that are used to test the significance of the parameters.

Table 5: The decomposition of the matrix $\Pi$

\begin{tabular}{|c|c|c|c|c|}
\hline \multicolumn{5}{|c|}{$\beta^{\prime}$} \\
\hline \multicolumn{3}{|c|}{ PRIHOD } & $\mathrm{BDP}$ & CONSTANT \\
\hline \multirow[t]{2}{*}{$\beta(1)$} & \multicolumn{2}{|c|}{1.000} & -0.394 & 4440.025 \\
\hline & \multicolumn{3}{|r|}{$[-30.669]$} & {$[4.772]$} \\
\hline \multicolumn{4}{|c|}{$\alpha$} & \\
\hline \multicolumn{4}{|c|}{$\alpha(1)$} & \\
\hline \multicolumn{2}{|c|}{$\triangle \mathrm{PR} I \mathrm{HOD}$} & $\begin{array}{r}-0 \\
{[-3 .}\end{array}$ & $\begin{array}{l}514 \\
54]\end{array}$ & \\
\hline \multicolumn{2}{|c|}{$\triangle \mathrm{BDP}$} & $\begin{array}{l}0.4 \\
{[1.7}\end{array}$ & & \\
\hline
\end{tabular}


From Table 5, it is apparent that the GDP and the constant component belong to the cointegration space (significant $t$ values). Reverse signs between $\alpha$ and $\beta$ coefficients indicate that the variables are returning to long-run equilibrium after leaving it, i.e. that we do not have so-called overshooting effect. Regarding the speed of adjustment, it can be concluded that the Revenues adjust to long-run equilibrium in little less than 2 quarters (-0614), while the GDP does not return to equilibrium after the model comes out of the long-run equilibrium $(t=1.772$ $(p<0.05))$; in other words, we can say that the GDP is a weakly exogenous variable, which does not adjust to a long-run equilibrium identified between these two variables. It follows that within the two quarters only Revenues adjust to a long-run equilibrium identified between these two variables.

Cointegration vector in Table 5 can be written in the form of equation:

$$
\text { Prihodi }=-\underset{(-4.772)}{4440.025}+\underset{(30.669)}{0.394} \mathrm{BDP}
$$

with $t$ values in brackets. Based on $t$ values, for which applies that their level of test significance $p<0.05$, in both cases it can be concluded that we can reject the hypothesis that the upper parameters are equal to zero. In other words, the GDP variable is statistically significant in explaining the trends of the variable Revenues, and the constant component is statistically significantly different from zero.

The above equation states that if, for example, GDP increases by one million HRK in prices in 2005, government revenues would increase by $394000 \mathrm{HRK}$ in prices in 2005, while if the GDP is zero (there are no taxes or contributions from which it could be financed) then the government budget would have a deficit of 4.440 billion HRK.

\section{GRANGER CAUSALITY}

Granger causality can be easily tested in a VAR setting. As Table 2 revealed that the optimal number of lags is 2, then in this case, the VAR model is reduced to:

$$
\begin{aligned}
(\text { Prihodi })_{t} & =v_{1}+a_{11}(\text { Prihodi })_{t-1}+a_{12}(\text { Pr ihodi })_{t-2}+a_{13}(B D P)_{t-1}+a_{14}(B D P)_{t-2}+u_{1} \\
(B D P)_{t} & =v_{2}+a_{21}(\text { Pr ihodi })_{t-1}+a_{22}(\text { Pr ihodi })_{t-2}+a_{23}(B D P)_{t-1}+a_{24}(B D P)_{t-2}+u_{2}
\end{aligned}
$$

To test whether the GDP has an impact on the revenues, in Granger sense, means simply to test the hypothesis $H_{0}: a_{13}=a_{14}=0$ on the VAR model parameters; while to test whether the revenues have an impact on GDP means to test the hypothesis $H_{0}: a_{21}=a_{22}=0$. Hypothesis $H_{0}: a_{13}=a_{14}=0$ can be rejected at a significance level of $5 \%$ as the result of testing is $F=13.4981(p=0.00004<0.05)$; while hypothesis $H_{0}: a_{21}=a_{22}=0$ cannot be rejected at a significance level of $5 \%$ as the result of testing is $F=0.8131$ ( $p=0.4519>0.05)$. In other words, we can say that GDP, in Granger sense, statistically significantly causes revenues, while revenues do not, in Granger sense, cause the GDP.

Therefore, the direction of activity between the variables is from the GDP towards the revenues. This result additionally confirms the result obtained by the cointegration analysis where it was found that GDP is weakly exogenous variable, i.e. that it does not adjust to a long-run stable relationship between revenues and GDP, but that a long-run cointegration relationship between GDP and revenues exists because the revenues adjust to that relationship within two quarters. 


\section{CONCLUSION}

This paper analyzed the relationship between government revenues in the Republic of Croatia and its GDP from the first quarter of 2000 until the first quarter of 2010. Values required for the analysis have been derived using cointegration analysis. All variables (GDP and budget revenues) that entered into the VAR model are reduced to real size (in prices in 2005) and seasonally adjusted. Using the augmented Dickey-Fuller test it has been concluded that they are I (1) processes that can be stationed if they are differentiated. Therefore, such processes are suitable for use in cointegration analysis. Cointegration analysis using Johansen's methodology indicated the existence of a statistically significant stable long-run relationship between GDP and the government budget revenues, which when normalized by the revenues variable looks like $\left[\begin{array}{ccc}\text { Prihodi } & B D P & \text { Konstant } a \\ 1 & -0.394 & 4.440\end{array}\right]$. It says that if the GDP increases, for example, by one billion of HRK, government budget revenues will adjust with the increase of 394 million HRK. If there would be no GDP, then the long-run relationship between the variables shows that the government budget would have the deficit of 4:44 billion HRK. Furthermore, it has been discovered that the government budget revenues adjust to the above mentioned long-run equilibrium within the two quarters, while the GDP is weakly exogenous variable that does not adjust to the long-run stable equilibrium. Further confirmation of these discoveries was obtained when testing Granger causality, i.e. that GDP has a significant impact on the government revenue trends, while budget revenues do not have impact, in Granger sense, on the GDP trends.

\section{REFERENCES}

Afonso, A., Furceri, D. (2008), "Government size composition, volatility and economic growth", European Central Bank - Working paper series, NO 849, January 2008

Barro, R. J., Redlick, C.J., (2009), "Macroeconomic Effects from Government Purchases and Taxes", National Bureau of Economic Research - Working paper series, September 2009, http://www.nber.org/papers/w15369

Benazic, M. (2006), "Fiscal Policy and Economic Activity in the Republic of Croatia: A Cointegration Analysis”, Ekonomski pregled , 57(12), pp. 882-917.

Doornik, J. A., Hansen, H. (2005), An Omnibus Test for Univariate and Multivariate Normality, Working Paper, Nuffield College, Oxford

Fuller, W. A. (1996), Introduction to Statistical Time Series, (2nd Ed.), New York, John Wiley

Godfrey, L. G., (1998), Misspecification Tests in Econometrics; the Lagrange Multiplier and other Approaches, Cambridge University Press

Granger, C.W.J.(1969), ”Investigating Causal Relations by Econometric Models and Cross Spectral Methods”, Econometrica, 37, str. 424-438.

Gray, C., Lane, T., Varoudakis A. (2007), Fiscal policy and economic growth - Lessons for Eastern Europe and Central Asia, The World Bank 
Johansen S., K. Juselius (1990), Maximum Likelihood Estimation and Inference on Cointegration with Application to the Demand for Money, Oxford Bulettin of Economics and Statistics 52, str. 169-209.

Johansen S. (1995), Likelihood-Based Inference in Cointegrated Vector Auto-Regression Models, Oxford Univerity Press.

Karras, G., Furceri, D. (2009), Taxes and growth in Europe, South-Eastern Europe Journal of Economics 2

Reimers H. E. (1993), Lag order determination in cointegrated VAR systems with application to small German Macro-Models, WP, ESEM, UPPSALA

Romero de Ávila, D., Strauch R. (2003), Public finances and long-term growth in Europe, European Central Bank, Working paper no. 246

Rukelj, D. (2009), Modelling Fiscal and Monetary Policy Interactions in Croatia Using Structural Vector Error Correction Model, Privredna kretanja i ekonomska politika 121, pp. 27-58.

Simovic, H. (2009), „Medjuovisnost oporezivanja i gospodarskog rasta u Hrvatskoj“, Ekonomska istrazivanja, Vol. 22, No. 1, 33-46.

Svaljek, S., Vizek, M., Mervar, A. (2009), Ciklicki prilagodjeni proracunski saldo: primjer Hrvatske. Privredna kretanja i ekonomska politika 120, pp. 49-81.

Tkalec, M., Vizek, M. (2010), Utjecaj makroekonomskih politika na preradjivacku industriju u Hrvatskoj 121 (19), Privredna kretanja i ekonomska politika, pp.61-93.

\section{ODNOS PRIHODA DRŽAVNOG PRORAČUNA I BRUTO DOMAĆEG PROIZVODA (BDP-a) U REPUBLICI HRVATSKOJ}

\section{$S A \check{Z} E T A K$}

Cilj ovoga rada je analizirati odnose između bruto domaćeg proizvoda (BDP-a) i prihoda državnog proračuna Republike Hrvatske za razdoblje od prvog kvartala 2000. do prvog kvartala 2010. godine.

Za analizu je korišten vektorski autoregresijski model. Međuovisnost između odabranih makroekonomskih veličina ispitivana je kointegracijskom analizom, kojom se dokazalo da postoji statistički značajna, dugoročna veza između bruto domaćeg proizvoda i prihoda državnog proračuna.

Testom Grangerove uzročnosti se dokazalo da bruto domaći proizvod ima značajan utjecaj, $u$ Grangerovom smislu, na prihode državnog proračuna.

JEL: E00, E01

Ključne riječi: kointegracijska analiza, Grangerova uzročnost, BDP, prihodi državnog proračuna 